\title{
LIETUVOS GYVENTOJŲ INFORMACIJOS APIE MITYBĄ ŠALTINIAI IR JŲ PASIRINKIMUI İTAKĄ DARANTYS VEIKSNIAI
}

\author{
Žymantas Žandaras, Valerij Dobrovolskij, Rimantas Stukas, \\ Rūta Maceinaitè, Rokas Arlauskas \\ Vilniaus universiteto Medicinos fakulteto Sveikatos mokslu institutas
}

\author{
Raktažodžiai: mityba, informacijos šaltiniai, informacija \\ apie mitybą.
}

\begin{abstract}
Santrauka
Daugelio Lietuvos gyventojų mitybos ịpročiai neatitinka sveikatos mitybos rekomendacijų. Sveikatai nepalankūs mitybos ịpročiai gali būti siejami su patikimos ir moksliniais tyrimais pagrisstos informacijos stoka. Ši informacija ịvairiomis priemonėmis (internetu, per televiziją, radiją ir kt.) gali būti perduodama gyventojams. Tik žinant, kokius informacijos apie mitybą šaltinius yra linkusios rinktis įvairios sociodemografinès grupès, galima nukreipti trūkstamą informaciją reikiama linkme ir suteikti reikalingų žinių. Tyrimo tikslas - įvertinti Lietuvos gyventojų informacijos apie mitybą šaltinius bei jų pasirinkimui įtaką darančius veiksnius. Tyrimo metu apklausti 1007 18-75 metų Lietuvos gyventojai. Paplitimo ịverčiams apskaičiuoti 95 proc. pasikliautinieji intervalai (PI). Nustatant veiksnius, galimai darančius ịtaką gyventojų informacijos apie mitybą šaltinių pasirinkimui, sudaryti logistinès regresijos modeliai, gauti pakoreguoti šansų santykiai, apskaičiuoti jų 95 proc. PI. Didžiausia Lietuvos gyventojų dalis gavo daugiausia informacijos apie mitybą iš interneto $(58,6$ proc.) bei radijo ir televizijos $(47,2$ proc.), o mažiausia - iš laikraščių ir žurnalų ( 16,5 proc.) bei maisto produktų etikečių ir pakuočių (18,8 proc.). Interneto, kaip šaltinio, iš kurio gaunama daugiausia informacijos apie mitybą, pasirinkimas buvo reikšmingai susijęs su išsilavinimu, radijo ir televizijos - su amžiumi, gyvenamąja vieta ir išsilavinimu. Moterys ir jaunesni nei 45 metų gyventojai buvo reikšmingai labiau linkę gauti daugiausia informacijos iš specializuotų leidinių bei maisto produktų pakuočių ir etikečių. Reikšmingai didesnị šansą gauti daugiausia informacijos iš gydytojų, vaistininkų, mitybos specialistų turejo moterys ir aukštojo išsilavinimo neturintys gyventojai. Laikraščiu ir žurnalų, kaip šaltinių, iš kurių gaunama daugiausia informacijos
\end{abstract}

apie mitybą, pasirinkimas buvo reikšmingai susijęs su lytimi, amžiumi, išsilavinimu, gyvenamaja vieta.

\section{Ivadas}

Pasaulio sveikatos organizacijos duomenimis, sveikatai nepalanki mityba laikoma vienu iš pagrindinių rizikos veiksnių, skatinančių lètinių neinfekcinių ligų, tokių kaip cukrinis diabetas, kraujotakos sistemos ligos, onkologiniai susirgimai, atsiradimą [1].

Lietuvos mokslininkų atliktų tyrimų rezultatai rodo, kad daugelio Lietuvos gyventojų mitybos ịpročiai neatitinka sveikos mitybos rekomendacijų: per mažai suvartojama vaisių ir daržovių, tik kas antras gyventojas kasdien vartoja grūdinius produktus, maisto racione per daug energinès vertès tiekia riebalai ir cukrūs, didžioji gyventojų dalis papildomai sūdo jau pagamintą maistą [2-4]. Kai kurie tyrimai rodo, kad mitybos ịpročiai gali būti siejami su gyventojų turima informacija ir žinioms [5-7]. Pagrindiniais informacijos apie mitybą šaltiniais laikomi internetas, televizija, šeimos nariai ir draugai $[8,9]$. Šiuolaikinèse interneto žiniasklaidos priemonèse (pvz., naujienų portalai, socialiniai tinklai, specialiosios programèlès ir kt.) ir ịprastiniuose informacijos šaltiniuose (žurnalai, laikraščiai, televizija, radijas) nuolat skelbiama ìvairi informacija apie mitybą, žmonèms skatinami rinktis ar vengti tam tikrų maistų produktų, jiems siūlomos ịvairios dietos, teikiami ịvairūs patarimai $[10,11]$. Ivvairūs informacijos šaltiniai gali būti panaudojami gyventojų mitybos raštingumo didinimui, tačiau geriausių rezultatų galima pasiekti tik tada, kai žurnaluose, straipsniuose, televizijos laidose ir kituose šaltiniuose bus pateikiama patikima ir moksliniais tyrimais pagrista informacija [11]. Žinant, kokius informacijos apie mitybą šaltinius yra linkusios rinktis ịvairios sociodemografinès grupès, galima nukreipti trūkstamą informaciją reikiama linkme, suteikti reikalingų žinių ir padèti formuotis sveikatai palankius mitybos ịpročius. Šios informacijos trūkumas lėmé tyrimo tikslą. 
Tyrimo tikslas - įvertinti Lietuvos gyventojų informacijos apie mitybą šaltinius bei šaltinių pasirinkimui įtaką darančius veiksnius

\section{Tyrimo medžiaga ir metodai}

Atliktas momentinis tyrimas, kurio tikslinè populiacija - Lietuvos 18-75 metu gyventojai. Atliekant tyrimą, panaudotas daugiapakopès stratifikuotos tikimybinès atrankos metodas, užtikrinantis duomenų reprezentatyvumą: kiekvienas Lietuvos gyventojas turèjo vienodą galimybę būti ịtrauktas i tyrimą, o tyrimo respondentai pagal tikslinius kriterijus (tokius kaip lytis, amžius, gyvenamoji vieta ir kitus) atitiko tikslinę populiaciją. Apskaičiuotas imties dydis - 1007 respondentai. Tyrimo priemonè - originali anketa, kurios dali sudare klausimai, skirti ịvertinti gyventojų pasirenkamus informacijos apie mitybą šaltinius.

Apklausa vykdyta 2019 m. kovo mėnesį. Taikytas kombinuotas tyrimo metodas: 60 proc. tiesioginio interviu metodu CAPI (angl. Computer assisted personal interview) ir 40 proc. internetinès apklausos metodu CAWI (angl. Computer assisted web interview). CAPI apklausą atliko profesionalus apklausejjas, kuris vede pokalbị su respondentu pagal parengtus klausimus, atsakymus fiksuodamas klausimyne. CAWI apklausoje respondentui buvo siunčiama nuoroda ị klausimyną, kurị respondentas užpildè savarankiškai jam patogiu metu. Nuoroda ị klausimyną yra

1 lentelè. Respondentų charakteristika $(\mathrm{n}=1007)$

\begin{tabular}{|c|c|c|}
\hline Požymiai & abs. sk. & proc. \\
\hline \multicolumn{3}{|l|}{ Lytis } \\
\hline Vyras & 476 & 47,3 \\
\hline Moteris & 531 & 52,7 \\
\hline \multicolumn{3}{|l|}{ Amžius } \\
\hline 45 m. ir jaunesni & 517 & 51,3 \\
\hline Vyresni nei 45 m. & 490 & 48,7 \\
\hline \multicolumn{3}{|l|}{ Gyvenamoji vieta } \\
\hline Kaimo vietovè & 297 & 29,5 \\
\hline Rajono centras, miestelis & 276 & 27,4 \\
\hline Didysis miestas & 434 & 43,1 \\
\hline \multicolumn{3}{|l|}{ Išsilavinimas } \\
\hline $\begin{array}{l}\text { Pagrindinis, vidurinis, nebaigtas aukštasis ir } \\
\text { pan., išskyrus aukštaji }\end{array}$ & 629 & 62,5 \\
\hline Aukštasis & 378 & 37,5 \\
\hline \multicolumn{3}{|l|}{ Šeiminė padėtis } \\
\hline Vienišas(-a), išsiskyręs(-usi) & 363 & 36,0 \\
\hline $\begin{array}{l}\text { Susituokęs(-usi), neįregistravęs(-usi) } \\
\text { santuokos }\end{array}$ & 644 & 64,0 \\
\hline \multicolumn{3}{|l|}{ Pajamos per mėnesi } \\
\hline $700 €$ ir mažiau & 574 & 57,0 \\
\hline Daugiau nei $700 €$ & 433 & 43,0 \\
\hline
\end{tabular}

unikali (klausimyno negalima užpildyti kelis kartus). Tyrimo metu apklausti 1007 18-75 metų Lietuvos gyventojai.

Duomenų analizė atlikta Stata bei WinPepi statistinėmis programomis. Siekiant rasti duomenų įkèlimo klaidas, buvo sudaromos kintamujų dažnių lentelès, nagrinèjamos neatitikimus galinčios atskleisti lentelès. Apskaičiuoti paplitimo iverčiai, 95 proc. PI. Siekiant išsiaiškinti, kokią įtaką Lietuvos gyventojų pasirenkamiems informacijos apie mitybą šaltiniams daro įvairūs veiksniai, sudaryti logistinès regresijos modeliai, gauti pakoreguoti šansų santykiai, apskaičiuoti jų 95 proc. PI. Skirtumas laikomas statistiškai reikšmingu kai $\mathrm{p} \leq 0,05$.

\section{Tyrimo rezultatai ir jų aptarimas}

Respondentų charakteristika. Tyrimo respondentai pagal lytị ir amžių pasiskirste panašiai: daugiau buvo moterų, nei vyrų (atitinkamai 47,3 proc. ir 52,7 proc.) bei 45 metų ir jaunesnių, nei vyresnių kaip 45 metų apklaustujų (atitinkamai 51,3 proc. ir 48,7 proc.). Iš visų 1007 tyrime dalyvavusių asmenų 43,1 proc. gyveno didžiuosiuose miestuose, kiti teigé gyvenantys rajono centre, miestelyje arba kaimo vietoveje. Daugiau nei pusè respondentų nebuvo ịgiję aukštojo išsilavinimo (62,5 proc.), buvo susituokę arba gyveno neįregistravę santuokos (64, proc.), jų ménesinès pajamos buvo 700 eurų ar mažiau (57,0 proc.) (1 lentelè).

Lietuvos gyventojų informacijos apie mitybą šaltiniai. Tyrimo rezultatai atskleide, kad didžiausia Lietuvos gyventojų dalis $(58,6$ proc.) informacijos apie mitybą daugiausia gauna iš interneto. Internetinių informacijos šaltinių populiarumą patvirtina ir kitų tyrëjų rezultatai $[8,12]$. Tokie rezultatai gali būti susiję su tuo, kad žmonès informacijos visomis temomis paprastai ieško internete.

Nustatyta, kad beveik pusé apklaustujų ( 47,2 proc.) daugiausia informacijos apie mitybą gavo iš radijo ir televizijos. Šių šaltinių svarbą patvirtino B. Tiozzo ir bendraautorių atliktas tyrimas, kuris parode, kad net 61,1 proc. gyventojų masines žiniasklaidos priemones (televiziją, radiją, laikraščius)

2 lentelè. Šaltiniai, iš kurių Lietuvos gyventojai sužino daugiausia informacijos apie mitybą $(\mathrm{n}=1007)$

\begin{tabular}{|l|l|l|l|}
\hline Informacijos šaltiniai & proc. & 95 proc. PI & $\mathbf{n}$ \\
\hline Internetas & 58,6 & 55,$5 ; 61,6$ & 590 \\
\hline Televizija, radijas & 47,2 & 44,$1 ; 50,3$ & 475 \\
\hline $\begin{array}{l}\text { Gydytojai, vaistininkai, mitybos spe- } \\
\text { cialistai }\end{array}$ & 36,0 & 33,$1 ; 39,1$ & 363 \\
\hline Šeima, draugai, bendradarbiai & 33,0 & 30,$1 ; 35,9$ & 332 \\
\hline $\begin{array}{l}\text { Specializuoti leidiniai apie mitybą ir } \\
\text { Sveikatą }\end{array}$ & 20,6 & 18,$2 ; 23,2$ & 207 \\
\hline Maisto produktų etiketės, pakuotės & 18,8 & 16,$5 ; 21,3$ & 189 \\
\hline Laikraščiai, žurnalai & 16,5 & 14,$3 ; 18,9$ & 166 \\
\hline
\end{tabular}


ịvardijo kaip pagrindinį informacijos apie mitybą šaltinį [12].

Iš gydytojų, vaistininkų ir mitybos specialistų informaciją gavo 36,0 proc. respondentų. Panaši dalis (33,0 proc.) teige informaciją gavę iš šeimos, draugų ir bendradarbių. Šie tyrimo rezultatai skiriasi nuo $2020 \mathrm{~m}$. publikuoto Bangladeše atliko tyrimo rezultatų, kuris atskleide, kad daugiausia respondentų $(52,4$ proc.) šeimos narius įvardijo kaip pagrindinį informacijos apie mitybą šaltini [13]. Tikètina, kad tokius rezultatų skirtumus galèjo lemti respondentų amžiaus (tyrime dalyvavo paaugliai) ir kultūriniai skirtumai. Mūsų tyrimo rezultatai taip pat atskleide, kad mažiausiai Lietuvos gyventojų informaciją apie mitybą gavo iš maisto produktų etikečių, pakuočių bei iš laikraščių ir žurnalų (2 lentelè).

Veiksniai, darantys įtaką Lietuvos gyventojų informacijos apie mitybą šaltinių pasirinkimui. Nagrinejjant veiksnius, galimai darančius įtaką Lietuvos gyventojų informacijos apie mitybą šaltiniu pasirinkimui, buvo nustatyta, kad aukštaji išsilavinimą turintys respondentai turèjo 1,99 karto didesnị šansą daugiausia informacijos gauti iš interneto, palyginus su kitą išsilavinimą igijusiais respondentais. Didesnị šansą gauti daugiausia informacijos iš interneto taip pat turejo moterys, jaunesni, bei didesnes pajamas gaunantys respondentai, tačiau šie skirtumai statistiškai reikšmingi nebuvo. Rezultatai parode, kad vyresni nei 45 metų apklaustieji, palyginus su 45 metų ir jaunesniais gyventojais, rajono centrų ir miestelių gyventojai, palyginus su didžiuosiuose miestuose gyvenančiais apklaustaisiais, bei pagrindini, vidurinị, profesinị ar kitą išsilavinimą turintys respondentai, palyginus su aukštajị išsilavinimą igijusiais gyventojais, turèjo reikšmingai didesnị šansą daugiausia informacijos apie mitybą gauti iš televizijos bei radijo (3 lentelè).

Tyrimas atskleide, kad aukštojo išsilavinimo neturintys gyventojai reikšmingai labiau buvo linkę daugiausia minètos informacijos gauti iš gydytojų, vaistininkų bei mitybos specialistų. Pažymètina, kad moterys, palyginus su vyrais, turëjo reikšmingai didesnị šansą kaip pagrindinị informacijos apie mitybą šaltinị rinktis specializuotus leidinius, laikraščius bei žurnalus, maisto produktų etiketes ir pakuotes, gydytojus, vaistininkus ir mitybos specialistus. Jaunesni respondentai daugiau informacijos apie mitybą gavo iš specializuoty leidinių bei produktų etikečių ir pakuočių, o vyresni - iš laikraščių ir žurnalų. Laikraščių ir žurnalų, kaip šaltinio, iš kurio gauna daugiausia informacijos apie mitybą, pasirinkimui reikšmingą ịtaką darè gyvenamoji vieta (didžiujų miestų gyventojai turèjo 1,58 karto didesnị šansą rinktis žurnalus ir laikraščius, palyginus su kaimo vietovių gyventojais) bei išsilavinimas (aukštajị išsilavinimą igiję respondentai turèjo 1,62 karto didesni šansą rinktis žurnalus ir laikraščius, palyginus su kitą išsilavinimą igijusiais apklaustaisiais) (3 lentelè). Svarbu paminèti, kad šeimos, draugų bei bendra-
3 lentelè. Veiksniai, darantys įtaką Lietuvos gyventojų informacijos apie mitybą šaltinių pasirinkimui

* $\mathrm{N}=1007$. Modelio tikètinumo santykio $\chi^{2}=48,35$, 1ls. $6, \mathrm{p}<0,0001$, Hosmer-Lemeshow testo $\chi^{2}=13,04,11 \mathrm{~s} .8, \mathrm{p}=0.110 . \mathrm{R}^{2} 0,035$.

** $\mathrm{N}=1007$. Modelio tikètinumo santykio $\chi^{2}=42,54,11 \mathrm{~s} .5, \mathrm{p}<0,0001$, Hosmer-Lemeshow testo $\chi^{2}=8,17,11 \mathrm{~s} .8, \mathrm{p}=0.415$. $\mathrm{R}^{2} 0,031$.

$* * * \mathrm{~N}=1007$. Modelio tikètinumo santykio $\chi^{2}=18,26,1 \mathrm{ss} .5, \mathrm{p}=0,003$, Hosmer-Lemeshow testo $\chi^{2}=9.25$, 1ls. $8, \mathrm{p}=0,322$. $\mathrm{R}^{2} 0,0139$

$* * * * \mathrm{~N}=1007$. Modelio tikètinumo santykio $\chi^{2}=15,03,1 \mathrm{~s} .3, \mathrm{p}=0,0018$, Hosmer-Lemeshow testo $\chi^{2}=1,23$, 1ls. 6, $\mathrm{p}=0.975$. $\mathrm{R}^{2} 0,0147$.

$* * * * * \mathrm{~N}=1007$. Modelio tikètinumo santykio $\chi^{2}=15,47,1 \mathrm{~s} .3, \mathrm{p}=0,0015$, Hosmer-Lemeshow testo $\chi^{2}=3,51$. 1ls. 5. $\mathrm{p}=0,637$. $\mathrm{R}^{2} 0,0159$.

$* * * * * * \mathrm{~N}=1007$. Modelio tikètinumo santykio $\chi^{2}=23,92$, 1ls. $6, \mathrm{p}=0,0005$, HosmerLemeshow testo $\chi^{2}=5,80,11 \mathrm{~s} .8, \mathrm{p}=0,670 . \mathrm{R}^{2} 0,0265$.

\begin{tabular}{|c|c|c|c|c|}
\hline Veiksniai & ŠS (b) & ŠS (p) & 95 proc. $\mathrm{PI}$ & $\underset{\text { reikšmė }}{\mathbf{p}}$ \\
\hline \multicolumn{5}{|c|}{ Daugiausia informacijos gauna iš INTERNETO* } \\
\hline \multicolumn{5}{|c|}{\begin{tabular}{l|l|l|l} 
Lytis & & & \\
\end{tabular}} \\
\hline Vyras & 1,00 & & & \\
\hline Moteris & 1,20 & 1,16 & 0,$90 ; 1,51$ & 0,239 \\
\hline \multicolumn{5}{|l|}{ Amžius } \\
\hline Vyresni nei $45 \mathrm{~m}$. & 1,00 & & & \\
\hline $45 \mathrm{~m}$. ir jaunesni & 1,44 & 1,29 & 0,$99 ; 1,67$ & 0,059 \\
\hline \multicolumn{5}{|l|}{ Gyvenamoji vieta } \\
\hline Kaimo vietovè & 1,00 & & & \\
\hline Rajono centras, miestelis & 1,22 & 1,10 & 0,$74 ; 1,54$ & 0,585 \\
\hline Didysis miestas & 1,67 & 1,23 & 0,$89 ; 1,71$ & 0,212 \\
\hline \multicolumn{5}{|l|}{ Išsilavinimas } \\
\hline Pagrindinis, vidurinis, & 1,00 & & & \\
\hline $\begin{array}{l}\text { profesinis ir kiti, išskyrus } \\
\text { aukštaji }\end{array}$ & 2,28 & 1,99 & 1,$49 ; 2,65$ & $<0,0001$ \\
\hline Aukštasis & 1,00 & & & \\
\hline $\begin{array}{l}\text { Pajamos per mėnesi } \\
700 € \text { ir mažiau } \\
\text { Daugiau nei } 700 €\end{array}$ & 1,64 & 1,23 & 0,$93 ; 1,65$ & 0,152 \\
\hline \multicolumn{5}{|c|}{ Daugiausia informacijos gauna iš TELEVIZIJOS, RADIJO** } \\
\hline $\begin{array}{l}\text { Amžius } \\
45 \text { m. ir jaunesni }\end{array}$ & 1,00 & & & \\
\hline $\begin{array}{l}\text { Vyresni nei } 45 \mathrm{~m} . \\
\text { Gyvenamoji vieta }\end{array}$ & 1,75 & 1,57 & 1,$22 ; 2,03$ & 0,001 \\
\hline Didysis miestas & 1,00 & & & \\
\hline Rajono centras, miestelis & 1,73 & 1,45 & 1,$05 ; 2,00$ & 0,023 \\
\hline Kaimo vietovè & 1,75 & 1,37 & 0,$99 ; 1,89$ & 0,054 \\
\hline \multicolumn{5}{|l|}{ Išsilavinimas } \\
\hline Aukštasis & 1,00 & & & \\
\hline $\begin{array}{l}\text { Pagrindinis, vidurinis, } \\
\text { profesinis ir kiti, išskyrus } \\
\text { aukštaji }\end{array}$ & $\begin{array}{l}1,60 \\
1,00\end{array}$ & 1,32 & 1,$01 ; 1,75$ & 0,049 \\
\hline $\begin{array}{l}\text { Pajamos per mėnesi } \\
\text { Daugiau nei } 700 € \\
700 € \text { ir mažiau }\end{array}$ & 1,70 & 1,29 & 0,$97 ; 1,70$ & 0,077 \\
\hline
\end{tabular}

darbių, kaip šaltinio, iš kurio gauna daugiausia informacijos apie mitybą, pasirinkimui, reikšmingos įtakos nedare nei vienas iš tirtų sociodemografinių veiksnių.

\section{Išvados}

1. Didžiausia Lietuvos gyventojų dalis gavo daugiausia 
Daugiausia informacijos gauna iš GYDYTOJŲ, VAISTININKŲ, MITYBOS SPECIALISTU****

\begin{tabular}{|l|c|c|c|c|}
\hline Lytis & 1,00 & & & \\
Vyras & 1,36 & 1,38 & 1,$06 ; 1,79$ & 0,017 \\
Moteris & & & & \\
Gyvenamoji vieta & 1,00 & & & \\
Didysis miestas & 1,21 & 1,09 & 0,$78 ; 1,52$ & 0,621 \\
Rajono centras, miestelis & 1,52 & 1,33 & 0,$95 ; 1,85$ & 0,094 \\
Kaimo vietove & 1,00 & & & \\
Išsilavinimas & 1,46 & 1,36 & 1,$02 ; 1,82$ & 0,037 \\
$\begin{array}{l}\text { Aukštasis } \\
\text { Pagrindinis, vidurinis, } \\
\text { profesinis ir kiti, išskyrus } \\
\text { aukštaji }\end{array}$ & 1,00 & & & \\
Pajamos per mėnesi & 1,33 & 1,14 & 0,$83 ; 1,49$ & 0,461 \\
Daugiau nei 700 € & & & & \\
$700 €$ ir mažiau & & & & \\
\hline
\end{tabular}

Daugiausia informacijos gauna iš SPECIALIZUOTŲ LEIDINIŲ APIE MITYBĄ IR SVEIKATĄ****

\begin{tabular}{|c|c|c|c|c|}
\hline Lytis & & & & \\
\hline Vyras & 1,00 & & & \\
\hline Moteris & 1,64 & 1,62 & 1,$18 ; 2,21$ & 0,003 \\
\hline Amžius & & & & \\
\hline Vyresni nei $45 \mathrm{~m}$. & 1,00 & & & \\
\hline $45 \mathrm{~m}$. ir jaunesni & 1,40 & 1,37 & 1,$00 ; 1,88$ & 0,046 \\
\hline $\begin{array}{l}\text { Išsilavinimas } \\
\text { Pagrindinis, vidurinis, }\end{array}$ & 1,00 & & & \\
\hline $\begin{array}{l}\text { profesinis ir kiti, išskyrus } \\
\text { aukštajji } \\
\text { Aukštasis }\end{array}$ & 1,20 & 1,16 & 0,$85 ; 1,60$ & 0,342 \\
\hline
\end{tabular}

informacijos apie mitybą iš interneto bei radijo, televizijos, o mažiausia - iš laikraščių, žurnalų bei maisto produktų etikečių ir pakuočių.

2. Moterys turejo reikšmingai didesnị šansą gauti daugiausia informacijos apie mitybą iš interneto, gydytojų, vaistininkų, mitybos specialistų, specializuotų leidinių, laikraščių, žurnalų bei maisto produktų etikečių ir pakuočių.

3. Vyresni gyventojai buvo labiau linkę gauti informaciją apie mitybą iš televizijos, radijo bei laikraščiu ir žurnalų, o jaunesni respondentai - iš interneto, specializuotų leidinių apie mitybą bei maisto produktų pakuočiu ir etikečių.

4. Didžiųjų miestų gyventojai, palyginus su kaimo gyventojais, turèjo reikšmingai didesni šansą gauti daugiausia informacijos apie mitybą iš laikraščių ir žurnalų, o rajonų centrų ir miestelių gyventojai, palyginus su didžiųų miestų respondentais, - iš radijo ir televizijos.

\section{Literatūra}

1. World Health Organization. Policy statement and recommended actions for lowering sugar intake and reducing prevalence of type 2 diabetes and obesity in the Eastern Mediterranean Region. 2016. WHO-EM/NUT/273/E. https://applications.emro. who.int/dsaf/EMROPUB_2016_en_18687.pdf?ua=1

Daugiausia informacijos gauna iš MAISTO PRODUKTU ETIKEČIŲ, PAKUOČIUU*****

Lytis

Vyras

Moteris

Amžius

Vyresni nei $45 \mathrm{~m}$.

$45 \mathrm{~m}$. ir jaunesni

Šeiminè padètis

S u s it u o kęs ( - u s i ),

gyvenantis(-ti) neįregis-

travus santuokos

Vienišas(-a), išsiskyręs

(-usi)

Daugiausia informacijos gauna iš LAIKRAŠČIŲ, ŽURNALŲ $* * * * * *$

Lytis

Vyras

Moteris

Amžius

$45 \mathrm{~m}$. ir jaunesni

Vyresni nei $45 \mathrm{~m}$.

Gyvenamoji vieta

Kaimo vietové

Rajono centras, miestelis

Didysis miestas

Išsilavinimas

Pagrindinis, vidurinis,

profesinis ir kiti, išskyrus

aukštaji

Aukštasis

Pajamos per mėnesị

Daugiau nei $700 €$

$700 €$ ir mažiau

\begin{tabular}{l|l|l|l}
1,00 & & & \\
1,53 & 1,51 & 1,$07 ; 2,14$ & 0,019 \\
1,00 & & & \\
1,42 & 1,53 & 1,$08 ; 2,17$ & 0,016 \\
1,00 & & & \\
1,29 & 1,22 & 0,$76 ; 1,95$ & 0,413 \\
1,54 & 1,58 & 1,$00 ; 2,47$ & 0,048 \\
1,00 & & & \\
1,65 & 1,62 & 1,$13 ; 2,33$ & 0,009 \\
1,00 & & & \\
1,04 & 1,24 & 0,$85 ; 1,82$ & 0,264 \\
& & &
\end{tabular}

\begin{tabular}{|c|c|c|c|}
1,00 & & & \\
1,59 & 1,59 & 1,$14 ; 2,20$ & 0,006 \\
1,00 & & & \\
1,57 & 1,57 & 1,$13 ; 2,17$ & 0,007 \\
1,00 & & & \\
1,00 & 1,07 & 0,$77 ; 1,50$ & 0,671 \\
& & & \\
& & &
\end{tabular}

2. Dobrovolskij V., Stukas R. Lietuvos gyventojų mitybos ịpročiai 2013 metais. Vilnius: Vilniaus universitetas, 2014. http:// smlpc.lt/media/file/Skyriu_info/Mityba_ir_fizinis_aktyvumas/ mitybos\%20DB/Lietuvos\%20gyventoju\%20mitybos\%20iprociai\%202013\%20metais.pdf

3. Barzda A., Bartkevičiūtè R., Baltušytė I., Stukas R., Bartkevičiūtè S. Suaugusių ir pagyvenusių Lietuvos gyventojų faktinès mitybos ir mitybos ịpročiu tyrimas. Visuomenès sveikata, 2016/1(72):85-94.

4. Grabauskas V., Klumbienė J., Petkevičienė J., Šakytė E., Kriaučionienė V., Veryga A. Suaugusių Lietuvos žmonių gyvensenos tyrimas, 2014. Kaunas: LSMU 2015:146. http://old.ntakd.lt/ files/Apklausos_ir_tyrimai/nacionalinio/2015/SGT2014.pdf

5. Kolodinsky J, Harvey-Berino JR, Berlin L, Johnson RK, Reynolds TW. Knowledge of current dietary guidelines and food choice by college students: better eaters have higher knowledge of dietary guidance. Journal of the American Dietetic Association. 2007;107(8):1409-13.

https://doi.org/10.1016/j.jada.2007.05.016

6. Miller LMS, Cassady DL. The effects of nutrition know- 
ledge on food label use. A review of the literature. Appetite 2015;92:207-16.

https://doi.org/10.1016/j.appet.2015.05.029

7. Höhn TD, Voigt C. Attitudes and media usage behavior surrounding nutrition. A survey among young families in Germany. Ernahrungs Umschau 2019;66(6):109-17.

8. Quaidoo EY, Ohemeng A, Amankwah-Poku M. Sources of nutrition information and level of nutrition knowledge among young adults in the Accra metropolis. BMC Public Health 2018;18(1). https://doi.org/10.1186/s12889-018-6159-1

9. Awofeso N, Gaber Y, Bamidele M. Determinants of youth engagement with health information on social media platforms in United Arab Emirates. Health 2019;11(02):249-62. https://doi.org/10.4236/health.2019.112022

10. Samoggia A, Riedel B. Assessment of nutrition-focused mobile apps' influence on consumers' healthy food behaviour and nutrition knowledge. Food Research International 2020;128:108766. https://doi.org/10.1016/j.foodres.2019.108766

11. Oteh OU, Obasi RO, Udodirim C, Amah J, Oteh AQ. Social media marketing and consumption of nutrition and dietary information among youths in Abia state, Nigeria. CJBSS 2019;10(2):26-44. https://journals.covenantuniversity.edu.ng/ index.php/cjbss/article/view/1800/1016

12. Tiozzo B, Pinto A, Mascarello G, Mantovani C, Ravarotto L. Which food safety information sources do Italian consumers prefer? Suggestions for the development of effective food risk communication. Journal of Risk Research. 2018;22(8):1062-77. https://doi.org/10.1080/13669877.2018.1440414

13. Kundu S, Khan MSI, Bakchi J, Sayeed A, Banna MdHA, Begum MR, et al. Sources of nutrition information and nutritional knowledge among school-going adolescents in Bangladesh. Public Health in Practice 2020;1:100030.

https://doi.org/10.1016/j.puhip.2020.100030

\section{SOURCES OF NUTRITION INFORMATION FOR THE LITHUANIAN POPULATION AND FACTORS AFFECTING THE CHOICE OF SOURCES \\ Ž. Žandaras, V. Dobrovolskij, R. Stukas, R. Maceinaitė, R. Arlauskas}

Keywords: nutrition, information sources, nutrition informa-
Summary

The diet of many Lithuanians do not comply with the recommendations of healthy nutrition. Unhealthy nutrition can be linked to a lack of reliable and research-based information. This information can be passed on to the population through various sources of information (internet, television, radio, etc.). Only by knowing which sources of nutrition information tend to be chosen by different sociodemographic groups, it is possible to provide the necessary information to these groups in a targeted manner. The aim of the study - to evaluate sources of nutrition information for the Lithuanian population and factors affecting the choice of sources. 1007 18-75-year-old Lithuanian residents were interviewed. 95\% confidence intervals (CIs) were calculated for prevalence estimates. In order to identify the factors that may influence the choice of sources of nutrition information for the population, logistic regression models were developed, adjusted odds ratios were obtained, and their 95 percent PI was calculated. The majority of population received the most information about nutrition from the internet $(58.6 \%)$, radio and television $(47.2 \%)$, while minority from newspapers, magazines $(16.5 \%)$ and food labels and packaging (18.8\%). Choosing internet, as a source from which the most information about nutrition is received, was significantly related to education; choosing radio and television - with age, place of residence and education. Women and the population under the age of 45 were significantly more likely to receive the most information about nutrition from specialized publications and food packaging labels. Women and the population without higher education had a significantly higher chance of receiving the most information about nutrition from doctors, pharmacists, and nutritionists. Choosing newspapers and magazines, as the sources from which the most nutrition information is received, was significantly related to gender, age, education, place of residence

Correspondence to: zymantas.zandaras@gmail.com

Gauta 2021-03-05 tion. 